\title{
THE EFFECTS OF DIHYDROERGOCORNINE ON THE CEREBRAL CIRCULATION OF PATIENTS WITH ESSENTIAL HYPERTENSION ${ }^{1}$
}

\author{
BY JOSEPH H. HAFKENSCHIEL, CHARLES W. CRUMPTON, 2 JOHN H. MOYER \\ AND WILLIAM A. JEFFERS WITH THE TECHNICAL ASSISTANCE OF BETTY \\ FISHEL HANLEY AND SALLY CONLIN HARNED \\ (From the Edward B. Robinette Foundation, Medical Clinic, Hospital of the University of \\ Pennsylvania, and the Department of Pharmacology of the School of \\ Medicine of the University of Pennsylvania, Philadelphia)
}

(Submitted for publication September 12, 1949; accepted, December 5, 1949)

The cerebral vascular resistance is increased in patients with essential hypertension as shown by cerebral blood flow measurements (1-3). Following differential spinal sympathetic block this high cerebral vascular resistance is reduced, coincident with a fall in arterial blood pressure (4, 5). However, the cerebral blood flow during the hypotensive period became significantly diminished. This inadequacy might be explained by the fact that differential spinal sympathetic anesthesia induces dilatation in the vascular beds of the regions blocked, and only indirectly affects the brain (6). Depressor drugs, such as adrenergic blocking agents administered parenterally, can act on the brain as well as on extracerebral areas and could have effects on cerebral blood flow and cerebral vascular resistance somewhat different from those of differential spinal block.

The effects of dihydrogenated derivatives of ergot on the blood pressure of patients with essential hypertension were first reported in 1947 (7). Later studies concerning the effect of these drugs on the peripheral circulation of normal men (8) and hypertensive patients $(9,10)$ have suggested that the dihydrogenated compounds derived from the ergotoxin fraction of the crude extract have depressor, vasodilator, and adrenolytic properties $(11,12)$. Among the dihydrogenated ergot compounds studied by Freis and his associates, dihydroergocornine was found to have the greatest hypotensive effect in essential hypertension (9).

1 This study was supported in part by a Research Grant from the National Heart Institute, U. S. Public Health Service, and in part by the Life Insurance Medical Research Fund.

2 Public Health Research Fellow of the National Heart Institute.
Normotensive patients, to whom dihydroergocornine was given, had insignificant decreases in cerebral blood flow, cerebral vascular resistance, and oxygen uptake. However, the mean arterial pressure was significantly decreased (13). This report is concerned with the effect of dihydroergocornine on mean arterial pressure, cerebral blood flow, cerebral oxygen uptake, and cerebral vascular resistance in 12 patients with essential hypertension.

\section{METHODS}

Patients with essential hypertension on the medical and surgical wards of the Hospital of the University of Pennsylvania were selected for these tests. All had marked hypertension (Table I), with retinopathy grades II to IV, fluoroscopic and electrocardiographic evidences of left ventricular hypertrophy, and moderate impairment of renal function as measured by PSP excretion and urea clearance tests. Only two patients (E. E. and E. P.), however, showed elevations of the blood urea nitrogen of mild degree (23 mgm.\%). E. E. showed signs of congestive heart failure at the time of admission. These signs had disappeared when the cerebral blood flow was measured.

After control measurements of cerebral blood flow (14), oxygen consumption and mean femoral arterial pressure (MABP) were made, the patient was given $0.3-0.5$ mgm. of dihydroergocornine (Sandoz DHO-180) ${ }^{3}$ intramuscularly. When the blood pressure reached its lowest level and remained there for ten minutes a second measurement of cerebral blood flow and oxygen consumption was made. This was usually about 60 minutes after the drug injection. All measurements were made in the supine position.

\section{RESULTS}

The effects of dihydroergocornine on mean arterial blood pressure, cerebral blood flow, cerebral vascular resistance, and cerebral oxygen metab-

3 This drug was furnished through the courtesy of the Sandoz Pharmaceuticals Company. 
TABLE I

Effects of dihydroergocornine on cerebral blood flow and cerebral oxygen metabolism

\begin{tabular}{|c|c|c|c|c|c|c|c|c|c|c|c|c|c|c|c|c|c|}
\hline \multirow{4}{*}{ Subject } & \multirow{4}{*}{$\begin{array}{c}\text { Time after } \\
\text { injection }\end{array}$} & \multirow{3}{*}{\multicolumn{2}{|c|}{$\begin{array}{c}\text { Mean } \\
\text { arterial } \\
\text { blood } \\
\text { pressure }\end{array}$}} & \multicolumn{6}{|c|}{ Cerebral } & \multicolumn{4}{|c|}{$\begin{array}{l}\text { Oxygen content } \\
\text { Vols. \% }\end{array}$} & \multirow{2}{*}{\multicolumn{2}{|c|}{$\begin{array}{c}\text { Cerebral } \\
\mathrm{A}-\mathrm{V} \mathrm{O}_{2} \\
\text { diff. }\end{array}$}} & \multirow{2}{*}{\multicolumn{2}{|c|}{$\underset{\mathrm{pCO}_{2}}{\text { Arterial }}$}} \\
\hline & & & & \multicolumn{2}{|c|}{$\begin{array}{l}\text { Blood } \\
\text { flow }\end{array}$} & \multicolumn{2}{|c|}{$\begin{array}{c}\mathrm{O}_{2} \\
\text { uptake }\end{array}$} & \multirow{2}{*}{\multicolumn{2}{|c|}{$\begin{array}{l}\text { Vasc. } \\
\text { resistance* }\end{array}$}} & \multirow{2}{*}{\multicolumn{2}{|c|}{$\begin{array}{c}\text { Femoral } \\
\text { artery }\end{array}$}} & \multirow{2}{*}{\multicolumn{2}{|c|}{ 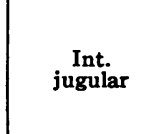 }} & & & & \\
\hline & & & & \multicolumn{4}{|c|}{ cc./100G./min. } & & & & & & & \multicolumn{2}{|c|}{ Vol. \% } & \multicolumn{2}{|c|}{$m m . H g$} \\
\hline & & Control & Drug & Control & Drug & Control & Drug & Control & Drug & Control & Drug & Control & Drug & Control & Drug & Control & Drug \\
\hline $\begin{array}{l}\text { L. O. } \\
\text { E. P. } \\
\text { W. M. } \\
\text { S. C. } \\
\text { E. A. } \\
\text { M. P. } \\
\text { W. M. } \\
\text { E. E. } \\
\text { H. T. } \\
\text { T. T. } \\
\text { F. K. } \\
\text { S. C. }\end{array}$ & $\begin{array}{l}40 \\
30 \\
60 \\
60 \\
60 \\
60 \\
60 \\
60 \\
60 \\
65 \\
60 \\
65\end{array}$ & $\begin{array}{l}178 \\
155 \\
136 \\
156 \\
180 \\
162 \\
132 \\
173 \\
135 \\
167 \\
172 \\
175\end{array}$ & $\begin{array}{r}132 \\
90 \\
120 \\
150 \\
64 \\
110 \\
118 \\
143 \\
116 \\
147 \\
125 \\
149\end{array}$ & $\begin{array}{l}44 \\
66 \\
64 \\
44 \\
69 \\
40 \\
51 \\
58 \\
54 \\
86 \\
61 \\
55\end{array}$ & $\begin{array}{l}48 \\
59 \\
63 \\
62 \\
46 \\
50 \\
58 \\
63 \\
65 \\
74 \\
53 \\
49\end{array}$ & $\begin{array}{l}3.7 \\
4.2 \\
4.2 \\
2.3 \\
4.6 \\
2.0 \\
3.1 \\
3.6 \\
3.4 \\
4.0 \\
2.8 \\
4.0\end{array}$ & $\begin{array}{l}3.8 \\
4.8 \\
3.7 \\
3.3 \\
3.8 \\
3.1 \\
3.2 \\
3.8 \\
3.6 \\
3.9 \\
2.4 \\
3.6\end{array}$ & $\begin{array}{l}4.0 \\
2.3 \\
2.1 \\
3.5 \\
2.7 \\
4.0 \\
2.6 \\
3.0 \\
2.5 \\
1.9 \\
2.8 \\
3.2\end{array}$ & $\begin{array}{l}2.6 \\
1.5 \\
1.9 \\
2.4 \\
1.4 \\
2.2 \\
2.0 \\
2.3 \\
1.8 \\
2.0 \\
2.4 \\
2.0\end{array}$ & $\begin{array}{l}17.7 \\
13.3 \\
19.1 \\
19.6 \\
17.7 \\
15.0 \\
17.2 \\
13.9 \\
19.1 \\
15.8 \\
17.8 \\
14.8\end{array}$ & $\begin{array}{l}17.7 \\
12.8 \\
18.0 \\
19.9 \\
16.6 \\
14.1 \\
17.2 \\
13.7 \\
18.3 \\
15.9 \\
16.7 \\
14.9\end{array}$ & $\begin{array}{r}9.3 \\
6.9 \\
12.6 \\
14.4 \\
11.0 \\
10.1 \\
11.1 \\
7.7 \\
12.8 \\
11.1 \\
13.2 \\
7.6\end{array}$ & $\begin{array}{r}9.5 \\
4.7 \\
12.2 \\
14.6 \\
8.4 \\
8.0 \\
11.7 \\
7.7 \\
12.7 \\
10.6 \\
12.1 \\
7.6\end{array}$ & $\begin{array}{l}8.4 \\
6.4 \\
6.5 \\
5.2 \\
6.7 \\
4.9 \\
6.1 \\
6.2 \\
6.3 \\
4.7 \\
4.6 \\
7.2\end{array}$ & $\begin{array}{l}8.2 \\
8.1 \\
5.8 \\
5.3 \\
8.2 \\
6.1 \\
5.5 \\
6.0 \\
5.6 \\
5.3 \\
4.6 \\
7.3\end{array}$ & $\begin{array}{l}37 \\
42 \\
40 \\
39 \\
36 \\
38 \\
38 \\
38 \\
35 \\
40 \\
43 \\
30\end{array}$ & $\begin{array}{l}38 \\
37 \\
39 \\
40 \\
35 \\
41 \\
41 \\
38 \\
36 \\
45 \\
43 \\
31\end{array}$ \\
\hline $\begin{array}{l}\text { Mean } \\
\text { Values }\end{array}$ & & 160 & $122 \dagger$ & 58 & 58 & 3.5 & 3.6 & 2.9 & $2.0+$ & 16.8 & 16.3 & 10.7 & 10.0 & 6.1 & 6.3 & 38 & 39 \\
\hline
\end{tabular}

* Cerebral Vascular Resistance $=$ Mean Arterial Blood Pressure divided by Cerebral Blood Flow. Cerebral Vascular Resistance $=\mathrm{mm}$. Hg./cc. blood $/ 100 \mathrm{G}$. brain $/ \mathrm{min}$.

† Signifies statistically significant differences from the control observations $(P<0.01)$.

olism are summarized in Table I. Following dihydroergocornine, significant reductions were found in mean arterial blood pressure, and cerebral vascular resistance. Mean cerebral blood flow did not change. Arterial carbon dioxide tension, cerebral oxygen consumption, and cerebral arteriovenous oxygen difference were essentially unchanged. Arterial and venous oxygen content decreased, but not significantly.

\section{DISCUSSION}

These tests show that the intramuscular administration of dihydroergocornine resulted in a considerable fall in mean arterial blood pressure in eight patients with essential hypertension. The other four had a lesser fall, the blood pressure of the group as a whole dropping $24 \%$. When the blood pressure became stabilized after the rapidly falling phase (usually about 30 to 50 minutes after injection), cerebral blood flow was found unchanged from the mean control values. No significant correlation appears to exist between the change in blood pressure and change in blood flow ( $r=0.37, p>0.1$ ).

The unchanged cerebral blood flow in the face of a decrease in mean arterial pressure indicates a significant decrease in cerebral vascular resistance $(2.9$ to $2.0, \mathrm{p}<0.01)$. This decrease in cerebral vascular resistance (averaging $31 \%$ for the 12 patients studied) appears to be of the same order of magnitude as the decrease in resistance found in the renal vascular bed $(25 \%)$ and the hepatic vascular bed (20\%) in one hypertensive patient reported by Wilkins (Figure 8 [10]) about 40 minutes following the administration of $0.4 \mathrm{mgm}$. of dihydroergocornine intravenously. A drop in total peripheral vascular resistance of about $32 \%$ approximately 30 minutes after the same amount of drug was injected intravenously in another patient is also reported by Wilkins (Figure 7 [10]). It is of interest that measurements of renal blood flow in this clinic before and 60 minutes after the intramuscular injection of 0.5 mgm. dihydroergocornine showed a significant increase in renal vascular resistance in four of five hypertensive patients studied (15).

From these findings it appears that the decrease in resistance in the vessels of the brain of a hypertensive patient after dihydroergocornine is such as to maintain constant cerebral blood flow, cerebral arteriovenous oxygen difference and cerebral 
oxygen uptake, in the face of a fall in mean blood pressure averaging $24 \%$.

A reasonable mechanism for such a result is a pharmacologic block of sympathetic vasoconstrictor impulses to the cerebral vessels. Some evidence presently available suggests this mechanism. Whereas differential spinal sympathetic block $(4,5)$ in patients with hypertension led to a fall in blood pressure of the same order as that seen after dihydroergocornine, it was only with the latter that the decrease in cerebral vascular resistance was great enough to prevent a decrease in cerebral blood flow and an increase in cerebral arteriovenous oxygen difference. Statistical analysis indicates that these differences in behavior of cerebral blood flow and cerebral vascular resistance following differential spinal block and $\mathrm{DHO}$ would each occur by chance alone but six in 100 times $(t=1.6)$. The likelihood that both differences would occur simply as the result of chance is therefore considerably less than 0.01 . The corresponding prediction for cerebral $\mathrm{A}-\mathrm{V}$ oxygen difference is about nine in 100 times $(t=1.4)$. Although these differences fall short of statistical significance individually because of the small number of observations, nevertheless, together they suggest an action of dihydroergocornine on the brain, in addition to a block of sympathetic vasoconstrictor influences in the splanchnic (16) and other regions, such as occurs following differential spinal anesthesia. This might be due primarily to a central action of the drug in inhibiting sympathetic vasoconstrictor impulses. The failure of bilateral stellate ganglion block to increase cerebral blood flow in patients with hypertension, however, is evidence against the presence of excessive sympathetic vasoconstrictor impulses traversing these pathways (17). More definitive experiments in normal and hypertensive persons are needed to clarify the possibility of an action on medullary centers $(7,9,11)$.

The arterial oxygen content decreased from 16.8 to 16.3 . We believe this to be due to the hemodilution resulting from the removal of about $100 \mathrm{cc}$. of blood from the circulation for the control measurements. This has been observed previously in normotensive patients (18).

\section{SUMMARY}

1. Measurements of cerebral blood flow, cerebral arteriovenous oxygen difference, and mean arterial blood pressure were made by the nitrous oxide method before and after the intramuscular injection of dihydroergocornine.

2. Cerebral blood flow, cerebral arteriovenous oxygen difference, and cerebral oxygen metabolism were unchanged when mean arterial blood pressure was significantly decreased.

3. It is concluded that dihydroergocornine appears to have produced a significant decrease in the cerebral vascular resistance allowing for cerebral metabolic homeostasis.

\section{BIBLIOGRAPHY}

1. Kety, S. S., Hafkenschiel, J. H., Jeffers, W. A., Leopold, I. H., and Shenkin, H. A., The blood flow, vascular resistance and oxygen consumption of the brain in essential hypertension. J. Clin. Invest., 1948, 27, 511.

2. Leopold, I. H., Kety, S. S., Jeffers, W. A., Hafkenschiel, J. H., and Shenkin, H. A., Correlation of the cerebrovascular resistance and the grade of hypertensive retinal findings. Am. J. Ophth., 1949, 32, 365 .

3. Hafkenschiel, J. H., Jr., Crumpton, C. W., and Moyer, J. H., Blood flow and oxygen consumption of the brain in coarctation of the aorta. Proc. Soc. Exper. Biol. \& Med., 1949, 71, 165.

4. Kety, S. S., King, B. D., Hafkenschiel, J. H., Horvath, S. M., and Jeffers, W. A., The cerebral circulation in essential hypertension and the effects of differential spinal sympathetic block. J. Clin. Invest., 1948, 27, 543.

5. Kety, S. S., King, B. D., Horvath, S. M., Jeffers, W. A., and Hafkenschiel, J. H., The effects of an acute reduction in blood pressure by means of differential spinal sympathetic block on the cerebral circulation of hypertensive patients. J. Clin. Invest., 1950, 29, 402.

6. Sarnoff, S. J., and Arrowood, J. G., Differential spinal block. Surgery, 1946, 20, 150.

7. Bluntschli, H. J., and Goetz, R. H., The effect of a new sympathicolytic drug (dihydroergocornine) on the blood pressure with special reference to hypertension. South African M. J., 1947, 21, 382.

8. Bluntschli, H. J., and Goetz, R. H., The effect of ergot derivatives on the circulation in man with special reference to two new hydrogenated compounds (dihydroergotamine and dihydroergocornine). Am. Heart J., 1948, 35, 873.

9. Freis, E. D., Stanton, J. R., and Wilkins, R. W., The effects of certain dihydrogenated alkaloids of er- 
got in hypertensive patients. Am. J. M. Sc., 1949, 216, 163.

10. Wilkins, R. W., Freis, E. D., and Stanton, J. R., Essential hypertension: laboratory studies in human beings with drugs recently introduced. J. A. M. A., 1949, 140, 261.

11. Nickerson, M., The pharmacology of adrenergic blockade. J. Pharm. \& Exper. Therap., 1949, 95, part 2, 27.

12. Goetz, R. H., and Katz, A., Adrenolytic action of dihydroergocornine in man. Lancet, 1949, 1, 560.

13. Hafkenschiel, J. H., Crumpton, C. W., and Moyer, J. H., The effects of intramuscular dihydroergocornine on the cerebral circulation in normotensive patients. J. Pharm. \& Exper. Therap., 1950, 98, 144.

14. Kety, S. S., and Schmidt, C. F., The nitrous oxide method for the quantitative determination of cerebral blood flow in man: theory, procedure and normal values. J. Clin. Invest., 1948, 27, 476.
15. Crosley, A. P., Cummins, A. J., Barker, H. G., and Clark, J. K., The renal hemodynamic effects of dihydroergocornine (DHO-180) in man. J. Pharm. \& Exper. Therap., 1950, 98, 138.

16. Kappert, A., Baumgartner, P., Daguet, A., Erard, H., Rupp, F., Schorer, D., and Zürcher, H. P., Untersuchungen uber die wirkungen neuer dihydrierter mutterkornalkaloide bei peripheren durchblutungsstörungen und hypertonie. Helvet. Med. Acta, 1949, Supp. 22, 16, 1.

17. Harmel, M. H., Hafkenschiel, J. H., Austin, G. M., Crumpton, C. W., and Kety, S. S., The effect of bilateral stellate ganglion block on the cerebral circulation in normotensive and hypertensive patients. J. Clin. Invest., 1949, 28, 415.

18. Kety, S. S., Woodford, R. B., Harmel, M. H., Freyhan, F. A., Appel, K. E., and Schmidt, C. F., Cerebral blood flow and metabolism in schizophrenia. Am. J. Psychiat., 1948, 104, 765. 